\title{
Returning To The Ranch?
}

\section{A revamped range curriculum at South Dakota State University helps students prepare to do just that.}

\section{By Kindra Gordon}

Many ranchers can attest that they've learned their life lessons through the school of hard knocks. Now, a new curriculum at South Dakota State University (SDSU) is designed to help future ranchers hit the ground running.

"We wanted to offer a program for our students who were planning to go back to the ranch," says Pat Johnson, a professor of range science at SDSU.

"We recognize that if you're going to manage a ranch, you need different skills than if you're going to work for an agency like the Natural Resources Conservation Service (NRCS)," adds Barry Dunn. Dunn has 20 years experience as a South Dakota rancher and is now a professor in the Animal and Range Science Department at SDSU.

So two years ago, a Range Livestock Production emphasis curriculum was created within the University's range science major. The coursework for the program is a blend of range science, animal science and business classes. The new curriculum was developed with input from a team of university professors, researchers, Extension specialists and ranchers.

Range science is at the core of the curriculum because of the crucial role it plays in the success of a ranch. "When you go back to the ranch and have grasslands to deal with, grazing becomes one of the most important things to understand and manage," Johnson says.

With that foundation, the program uses an integrated approach to bring the three elements of business management, grazing, and livestock production together. Based on input from seasoned ranchers in the state, the program also devotes time to learning how to analyze records, as well as understanding human behavior and working with family.

This well-rounded combination is designed to help students who want to return to the farm or ranch, leave SDSU with a solid education in managing rangeland from a rancher's perspective. "We want our graduates to have practical experience in understanding all of the elements of ranching," Johnson says.

To that end, one of the initial courses for freshman and sophomore students enrolled in the program is designed to offer an overview of ranch management. "From the start, we want to sensitize students to the breadth and depth of information they'll need to be a successful ranch manager," says Dunn.

"Our goal is to help students look at a ranch holistically and realize that it includes people, communities, natural resources and finances, in addition to the livestock," he adds.

In the introductory class, students work as a team to develop ranch plans, conduct resource inventories and set ranch goals. By their senior year, SDSU students formulate their own ranch plans in the advanced ranch management course, which focuses on in-depth business

\section{Other Range Options}

At the same time SDSU retooled its "back to the ranch" curriculum, two other emphasis areas were also redesigned for range science students: a rangeland resource conservation emphasis and a rangeland ecology and habitat management emphasis.

Johnson says the ecology and habitat emphasis includes mostly coursework targeting the science and ecological side of rangelands; whereas the resource conservation emphasis is more a blend of the sciences and the practical production courses. Students in the conservation emphasis would primarily be preparing for careers with various government agencies such as the Natural Resources Conservation Service, Forest Service and Bureau of Land Management.

As a side note, Johnson says job opportunities in the range science arena are expected to increase in coming years. "It looks like there will be a good opportunity for range science graduates to work with the federal government in the future." She says that's due the additional conservation funding in the new farm bill, as well as a high rate of federal employees retiring.

She adds, "We've seen some universities move away from offering specific curricula in range training. So with fewer range graduates out there, even more opportunities should become available." 
analysis. Dunn says the goal of this final course is to assist these future ranchers in developing a plan to help make their hopes and dreams come true.

Not surprisingly, the feedback from students has been overwhelmingly positive. Dunn says the most frequent comment students make after completing the introductory course is: "I didn't realize there was so much to it."

He adds, "And, why would they? Most of them are 18 years old, and their folks have never shared a balance sheet with them. Our goal is to expose them to all of the elements required to manage a successful ranch."

Johnson and Dunn report that several students are taking courses in the new "back to the ranch" curriculum, and there has been a noticeable increase in the number of incoming freshmen enrolling in the range livestock production program.

Johnson adds that the success of their newly revamped program is also due to the support they received from other departments at SDSU. "The animal science and wildlife professors were very supportive of our efforts to redesign the range curriculum. We all want to help students take courses that suit their career needs," she says.

\section{Required Reading}

As part of the Range Livestock Production coursework at SDSU, professor Barry Dunn requires his students to do a lot of reading. On his list of must reads is the book Centennial by James Michener. Dunn says this is a very good resource for anyone involved in the ranching community. The book profiles the geological development of the Great Plains, as well as highlights stories of the transfer of several family ranches from one generation to the next. He says the book gives a realistic view of ranching and shares some stories that were successes and others that were not.

Editor's Note: If your University has recently implemented changes to its range science or natural resource curriculum, let us know. We'd like to feature it in a future issue of Rangelands, contact Kindra Gordon at kindras@gordonresources.com.

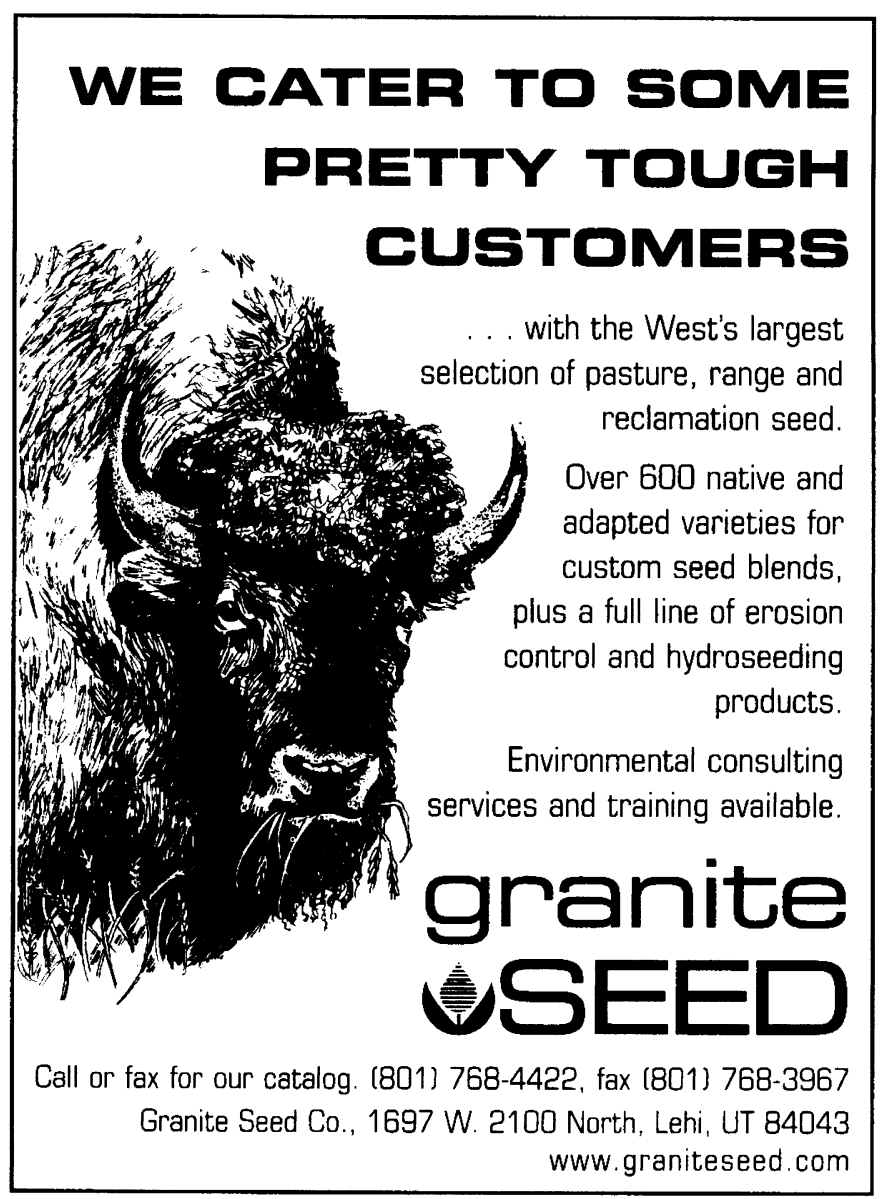

